\title{
LIFE AND PROFESSIONAL ACTIVITIES OF A GRADUATE OF THE DEPARTMENT OF ENGINEERING OF RIGA POLYTECHNIC INSTITUTE MIKHAIL KRIVOSHAPKIN (1888-1943)
}

TATJANA FEIGMANE* Institute of Russian Cultural Heritage of Latvia LIENA IVONNA ŠERVINSKA Latvian Association of Architects

Summary. Rigan, a graduate of the Department of Engineering (1914) of Riga Polytechnic Institute (RPI) Mikhail Krivoshapkin, after studies worked as an engineer in Russia, where he built grain elevators. From 1920 until deportation to Siberia in 1941 he lived in Riga and was the author of several bridge projects in Latvia, worked as an engineer at Riga Construction Board and was a member of the Riga City Council (1925-1934). He worked in various public organizations. His descendants - grandchildren and great-grandchildren also pursue careers in engineering.

Keywords: Mikhail Krivoshapkin, graduates of Riga Polytechnic Institute, Latvian engineers.

\section{Family, Childhood and Youth of M. Krivoshapkin}

Mikhail Krivoshapkin (Михаил Кривошапкин; 1888-1943) was born in Riga on 19 October 1888 ${ }^{1}$. His father, Dmitry Krivoshapkin (Димитрий Кривошапкин; 1844-1906), was born in Russia, in the Vologda province (at present - Vologda region) in a family of Russian peasants. The father served in the army and advanced to the rank of

\footnotetext{
${ }^{1}$ The dates in publication are listed according to the Gregorian calendar or new style.

* Corresponding author.

E-mail: t.feigmane@inbox.lv
} 
sergeant major. D. Krivoshapkin was awarded the Cross of St. George IV class. In 1875, he married a peasant, an Orthodox Latvian born in Puikule parish, Jevgenija Zake (also Zakke; 1855-1942). The wedding ceremony took place at the Orthodox Church of Transfiguration of Christ in Jaunjelgava city [1]. Soon the family moved to Riga city.

Jegennija's brother, Andrejs Zakis (also Zakke; 1834-1899), was the first Latvian Orthodox Bishop known as Alexander. In 1883, he was appointed the Bishop of Ostrozhska and the Vicar of Diocese of Volhynia; from 1890 to 1893, he was the Bishop of Arkhangelsk and Kholmogory, Alexander's last position was of the Bishop of Polotsk-Vitebsk [2].

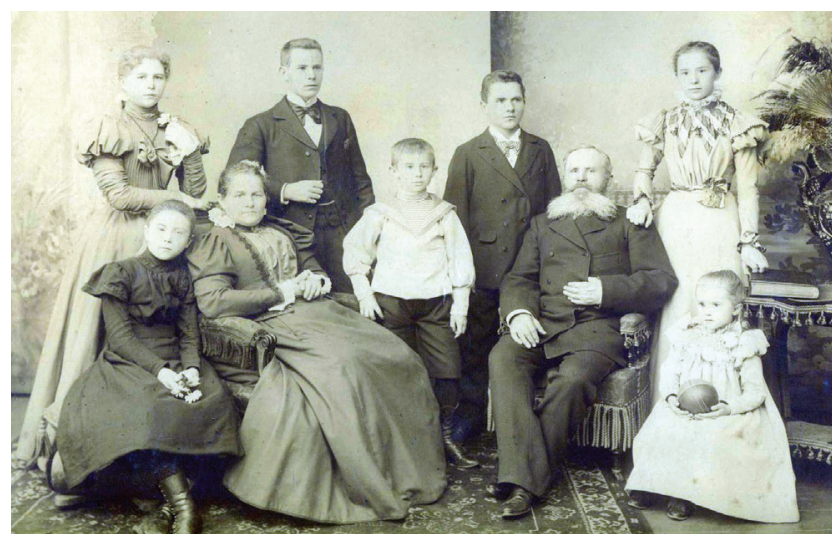

Figure 1. The family of

M. Krivoshapkin (1898). 1st row from left: Aleksandra (1886-1955), parents Jevgēnija (1855-1942) and Dmitry (1844-1906) Krivoshapkins, between them - Mikhail (1888-1943), Natālija (1892-1946); 2nd row: Lidija (1878-1966), their relatives - two brothers Podprugins from Vologda and Marija (1880-1968) [3].

Jevgēnija and Dmitry had five children: four daughters and a son.

Aleksandra married architect Vladimir Shervinsky (Владимир Шервинский; 1894-1975), Natālija's surname after marriage was Djakonov, and Lidija married in 1898 to priest Jānis Krampis (1872-1945). Daughter of Lidija and Jānis, Vera Krampe (1907-1977) was an opera singer. The third daughter of M. Krivoshapkin, Marija, got married to Adrian Njikiforovsky (Адриан Никифоровский; 1875-1914), the priest of the village of Kurilovska in the province of Vitebsk [4; 5].

In 1905, the family suffered a great misfortune - the head of the family, who worked as a casier at the time, was attacked; he was shot and died in 1906 at the hospital.

At that time, Mikhail Krivoshapkin was still studying at the Riga Alexander Gymnasium for Men from which he graduated in 1908. In the same year, M. Krivoshapkin enrolled in the Department of Engineering of RPI [6]. During his studies, on 9 February 1909, M. Krivoshapkin joined the Russian Student Corporation «Fraternitas Arctica» and received the «colours» on 2 September 1909; i. e., he became a full member of the corporation. At the beginning of the 1920s he was one of the founders of the aforementioned student corporation. It is known that in 1938 and 1939, 
M. Krivoshapkin was the Chairman of the Association of Old Members of Student Corporation «Fraternitas Arctica» [7].

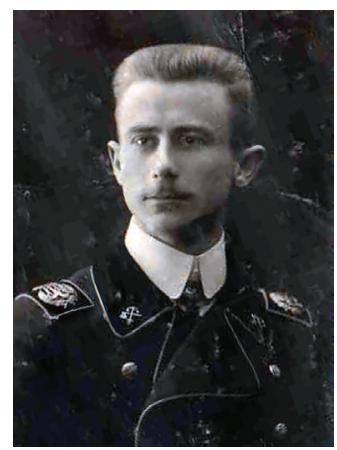

Figure 2.

M. Krivoshapkin

(1908) [8].

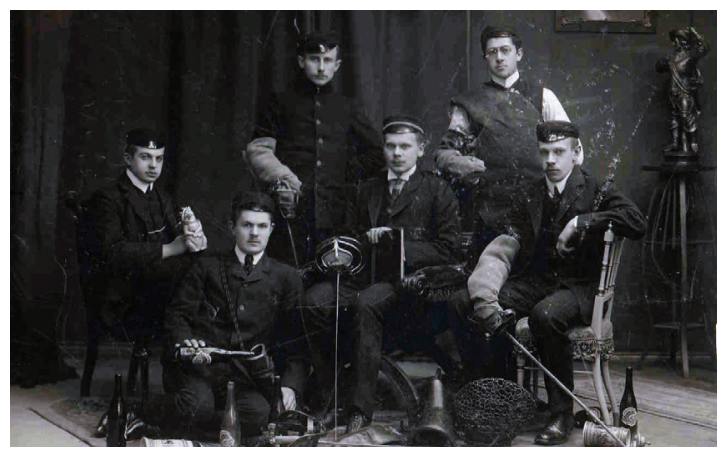

Figure 3. Russian Student Corporation «Fraternitas Arctica» in study year 1908/1909. From left:

Stepan Sawernjajew (Степан Заверняев), Piotr Winogradow (Петр Виноградов), Mikhail Krivoshapkin, Nikolai von Essen (Николай фон Эссен), Iwan Lassmann (Иван Лассман), Friedrich Leesmann (Фридрих Леесман) [9].

Already during his studies Mikhail Krivoshapkin began practicing as an engineer. He describes the beginning of his career: «In summer of 1911 I worked in Joint Stock Company of Valmiera Narrow-Gauge Railway as a trainee for researching the Inčukalns-Jaunpiebalga-Vecpiebalga-Smiltene line and in the development of the project, later also in the installation of the railway line. In the summer of 1912, I worked as a trainee in Saratov and later I held the position as the job manager for the sewerage building of this city. In the summer of 1913, I worked in Riga city with «Karl Kalt» as a work manager in the establishment of Riga City sewerage and took part in reconstruction of the brick arch of bridge across the city canal in Kr. Barona iela» [10].

In 1914, M. Krivoshapkin graduated from the Department of Engineering of RPI with an excellent civil engineer degree. The subject of the diploma project was «Двухшарнирная арка с затяжкой через реку Оку

Figure 4. M. Krivoshapkin works with a leveler in Jaunpiebalga city (1911) [11].

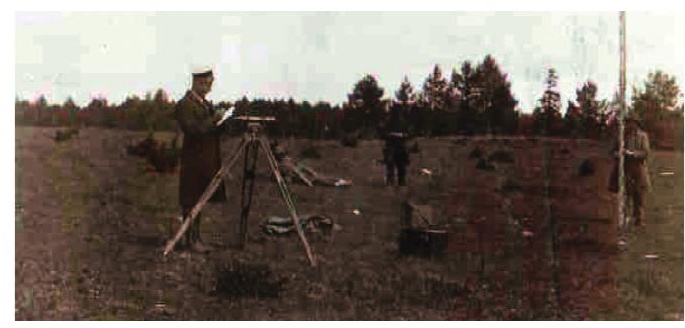


в Нижнем Новгороде» («Dvuhsharnaja arka s zatjazhkoij cherez reku Oku v Njizhnjem Novgorodje»/«Two-hinge arch with lace over the River in Nizhny Novgorod»).

\section{Work of M. Krivoshapkin in Russia (1914-1920)}

In a copy of the diploma issued on 5 June 1914, it is written that «Mikhail Krivoshapkin has been granted the right to carry out all types of construction work and to design all types of buildings and structures; entering full-time post in the relevant public service» [12].

In 1914, there was another significant event in the life of M. Krivoshapkin - on May 22 he married the daughter of the State Councillor Nina Scherwinsky (Нина Шервинская; 1892-1942). Father of Nina - Max Scherwinsky (Максим Шервинский; 1859-1909) - was an architect, one of the art nouveau pioneers in Riga. He was also a teacher and Director of the Riga German Craft School.

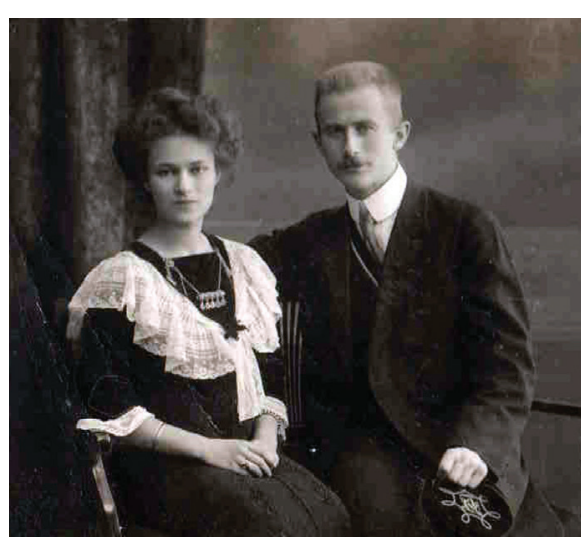

Figure 5. Nina and Mikhail Krivoshapkins (1914) [13].

Mikhail and Nina was known eight years before the wedding. Gymnast Mikhail met Nina thanks to his sister Aleksandra, who studied with Nina at the Lomonosov Gymnasium. Nina and Mikhail Krivoshapkins lived happily in their marriage for 27 years.

In his biography, M. Krivoshapkin wrote: «After graduating from Riga Polytechnic Institute, I was invited to stay in the Department of Bridges to prepare for scientific work; the offer was made by the Head of the Department of Bridges and Dean Professor Vodzinskis. World War I, which occurred at the time of the institute's closure, deprived the opportunity to accept this professor's call» [14].

To find a job, M. Krivoshapkin and his new wife went to the capital of the Russian Empire St. Petersburg. 
According to the recommendations of Director of RPI Woldemar von Knieriem, M. Krivoshapkin entered the German company «Philip Holtzman \& Co» dealing with underground and surface engineering. But when the World War I began, the company was wound up and the engineer was forced to look for a new job.

In his autobiography, M. Krivoshpkin wrote that on 5 August 1914 he entered the service at the Department of Grain Elevator Buildings of the Russian State Bank as engineer for projecting high-rise concrete structures and iron bridges. In 1915 he led the construction of grain elevator in Borisoglebsk, the province of Tambov. There was built a 32-meter high-reinforced concrete and silo-building with a 12-meter high wooden extension; brick building for machines with a 45 meters high brick chimney; two-storey and one-storey stone buildings; railroad and cobblestone. The cost of the buildings was approximately one million gold rubles.

In 1916, M. Krivoshapkin led the construction of grain elevator at the Altata station in province of Samara (at present - Saratov region). The following works were carried out there: a 24-meter high-reinforced concrete and silo-building with a 12-meter high wooden silo-extension were built; one-storey stone building, farm buildings, railroad, reinforced concrete bridge were built. The total cost of the buildings was around 500000 gold rubles.

Figure 6. Construction of grain elevator in Altata (1916) [15].

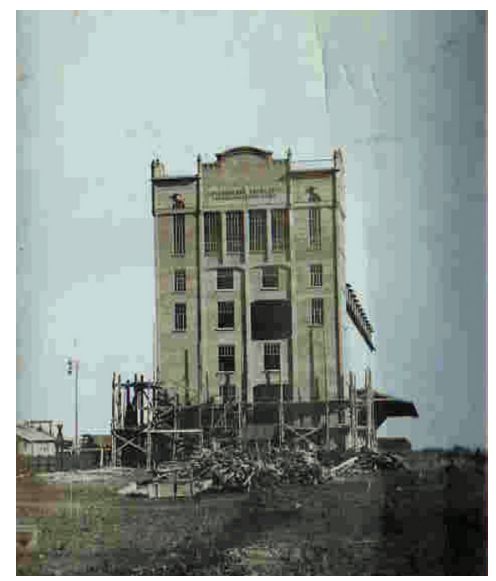

In 1918, M. Krivoshapkin led the grain elevator building at the Atkarsk, the province of Saratov and at the same time assembled the elevators' machines at the Petrovsk. From 1919 to 1920, he headed the Technical Department of the Elevators Building of Saratov Province and was in charge of the new construction and repairs at the Department of Food of Saratov Province. 
In September 1920, M. Krivoshapkin and his family left Soviet Russia and returned to their home country, Latvia. In Russia, two children were born in the family: Boriss (1916-1990) and Ksenija (1917-1918). The youngest children were born in Latvia: Vladimirs (1923-1942) and Natālija (1931).

\section{Activities of Engineer in Latvia}

On 1 October 1920, M. Krivoshapkin started working at the Department of Bridges of the Board of Roads and Construction at the Latvian Ministry of Transport as Senior Engineer. In his autobiography, M. Krivoshapkin described the situation as follows: «With the abolition of the Board of Road and Construction on 1 April 1921 I remained at the reorganized Board of Highway and Land Road as a Bridge Engineer» [16].

In January 1922, M. Krivoshapkin oversaw the inspection and improvement of the Old Iron (Ralway) Bridge in Riga.

Together with the graduate of RPI (1911), lecturer of the University of Latvia, engineer Pāvils Pāvulāns (1883-1956), was developed several project versions of the bridge across the Lielupe river.

In 1923, a Pontoon Bridge across the Venta river was built in Ventspils city after the project of M. Krivoshapkin. It was opened on 21 October 1923 [17]. The Pontoon Bridge was built by contractor E. Bauls. The Wooden Bridge was 174.6 meters long and 8.5 meters wide and served until 1964 when the new reinforced concrete bridge was built. The bridge was rotatable in order not to interfere with marine traffic. The construction of the bridge cost the government about 50000 lats.

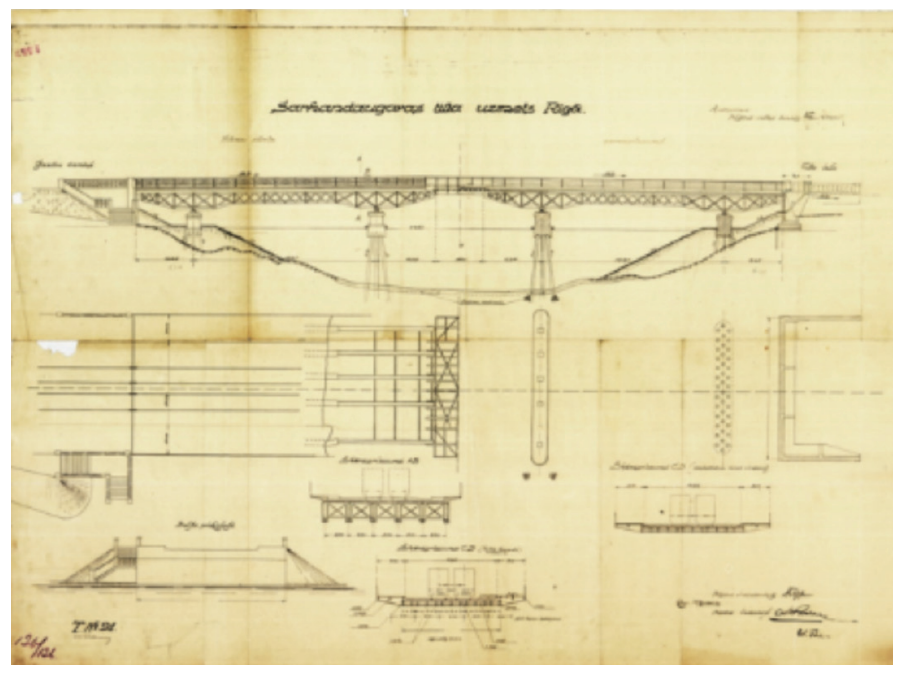

Figure 7. Project of reinforced concrete bridge across the Sarkandaugava armlet (in the 1920s) [19]. 
In 1929, after the project of M. Krivoshpkin in Riga, a reinforced concrete bridge over Sarkandaugava armlet was built. In total, the engineer participated in designing more than 100 different sizes of bridges [18].

In 1923, M. Krivoshapkin, together with his wife's brother architect Vladimir Shervinsky, established a private project company, where many projects were developed under their leadership, such as: project of the Riga Russian Theatre Reconstruction, project of Ainaži Four-Class Primary School building, reconstruction projects of many private buildings, research for constructions of St. John the Forerunner Church in Riga and many other objects [20]. Company was successful until 1940 [21].

Already in 1925, M. Krivoshapkin was offered to construct a hanging bridge across the Daugava river, forcing it to be 610 meters long with two 43 meter high iron towers. Engineer predicted it between $\mathrm{Kr}$. Valdemāra iela and Ägenskalns Steamboat Pier. The proposal was apparently premature and was not accepted by the Construction Board [22].

From 1924 to 1941, M. Krivoshapkin worked at the Construction Board of Riga City Council. He was a civil engineer and a member of the Audit Committee. The engineer was responsible for monitoring the progress of the construction works and the condition of the existing bridges.

One of the most pressing problems of the city's economy was the lack of connection between the two banks of the Daugava river. A Pontoon Bridge was built at the end of the 19th century and a horse railway was built on it at the beginning of the 20th century. During World War I an attempt to evacuate the bridge failed because the storm thrown it off the shore. Instead, the Luebeck Bridge was built from wooden trusses, but in 1924 it was destroyed by spring floods [23], so the main task of Riga City Council was to build a new pontoon bridge across the Daugava river.

Supervision of the construction of bridge was entrusted to the city engineer M. Krivoshapkin. The bridge was opened in 1931 and was located around the current Akmens (Stone) Bridge. On the suggestion of

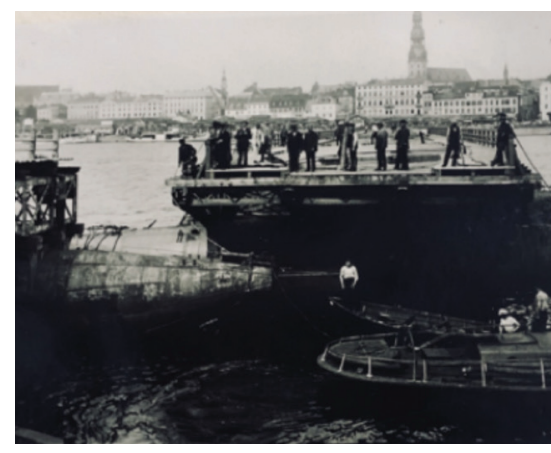

Figure 8. Construction of a Pontoon Bridge in Riga city (1931) [24].

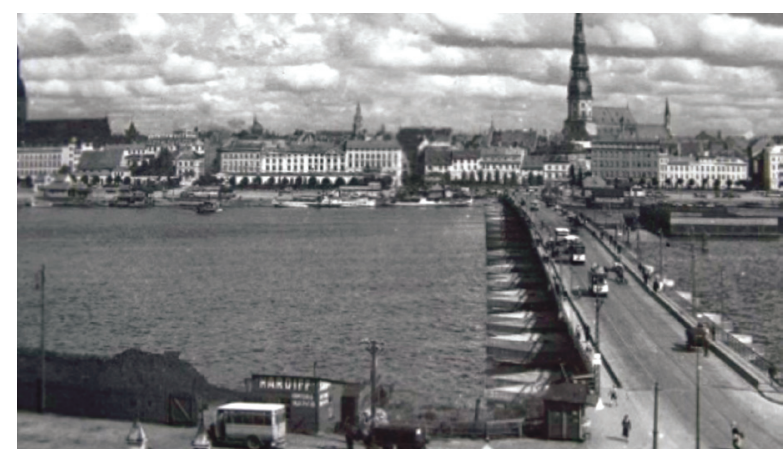

Figure 9. The Pontoon Bridge in Riga (in the 1930s) [25].
Life and

Professional Activities of a Graduate of the Department of Engineering of Riga Polytechnic Institute Mikhail Krivoshapkin (1888-1943) 
M. Krivoshapkin, tram lines were placed on the bridge in two directions. Pavement pedestrians were laid, electric lighting was installed. During World War II the bridge was destroyed.

From 1924 to 1940 M. Krivoshapkin joined the duties of an engineer with the teacher's work (in the evenings) at Riga City Craftsman School and Technical School at 4 Gaizina iela, where he read lectures on bridge construction, ground and road works [26].

The fact that he has been published in the biographical guide «Es vinu pazistu» («I know him») is a testimony to M. Krivoshapkins' merits and engineer's work. It is noted that M. Krivoshapkins was the manager of the Department of Bridges of the Department of Construction at the Riga Construction Board, designed a bridge over the Venta river in Ventspils city, a Pontoon Bridge in Rig city, a bridge over Sarkandaugava armlet and others [27].

\section{Social and Political Activities of M. Krivoshapkin in Latvia}

M. Krivoshapkin was known in Latvia not only as a talented engineer but also a tireless participant of several Russian public organizations.

Already in the early 1920s, M. Krivoshapkin joined the most influential Russian organizations at the time: the Russian National Union in Latvia and the Russian National Association in Latvia and these organizations also nominated him to the Riga City Council and the Saeima. He was entrusted with the duties of Chairman of the Election Committee of the Russian National Association in Latvia.

Engineer M. Krivoshapkin took part in the elections in the 2nd, 3rd and 4th Saeima. In 1925, he was nominated from a list of «Candidates of Orthodox Voters and Russian Unified Organizations Block», led by Archbishop Jānis Pommers (1876-1934) of the Latvian Orthodox Church. It was the first political experience of M. Krivoshapkin. He was not elected to the Saeima [28]. In the 3rd and 4th Saeima elections in 1928 and 1931, M. Krivoshapkin remained faithful to the political course he had chosen [29; 30]. True, the title of the list changed a little over time,and M. Krivoshapkin was nominated for a list of «Candidates of Orthodox and Old Believers Voters and United Russian Organizations». In 1928, M. Krivoshapkin was already an experienced councillor of Riga City Council and had no particular desire to become a Deputy of the Saeima.

M. Krivoshapkin was closely associated with the Riga City Council. He was an engineer, so economic and urban improvements were closer to him than politics. 
For the first time, M. Krivoshapkin was elected as a Deputy of the Riga City Council in February 1925 together with an architect, a graduate of the Department of Architecture (1904) of RPI Pjotr Ladigin (Пеmp Ладыгин; 1879-?). In 1928, M. Krivoshapkin repeated his success in elections. The third candidate, Boris Shalfejev (Борис Шалфеев; 1891-1935), was also elected from the list of «Russian Organizations». In 1931 M. Krivoshapkin was once again elected to the Riga City Council. But his colleague by P. Ladigin, was replaced by Kirill Jankovich (Кирил Янкович; 1858-1939) [31].

Figure 10. M. Krivoshapkin (in the 1930s) [32].

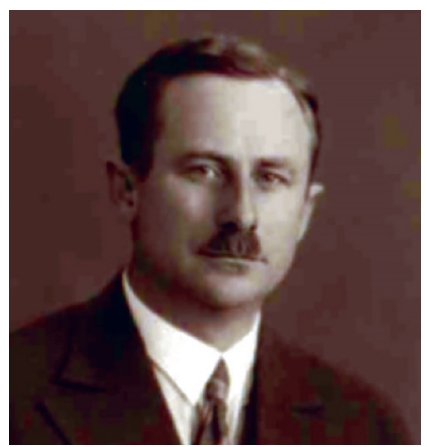

From 1924 to 1940, M. Krivoshapkin was a member of the Russian National Union in Latvia (since 1939 - Riga Russian Society) and was reelected as a Member of the Board [33].

According to the data of 1938, M. Krivoshapkin was a Member of the Board of the Russian National Union, the Chairman of the Student Corporation «Fraternitas Arctica», the Vice-Chairman of the Russian Society of Engineers, the Member of the Board of «Riga Charity Society for Poor Russians», Secretary of the Board of «Friendly Society of Russian Theatre», Senior Member of the Russian Gymnastics Society «Сокол» («Sokol») [34], as well as took part in several other public organizations, including the Association for the Promotion of Academic Education. As a Member of the Riga City Council, he financially supported the Institute of Sciences of Russian University, promoting the granting of subsidies [35].

Since 1930, M. Krivoshapkin has been Member of the Russian Gymnastics Society «Сокол» («Sokol») [36], which is known for his right, monarchic beliefs. In 1933, the organization split into the creation of «Русский сокол» («Russkij sokol») and «Русская сокольня» («Russkaya Sokolnja»). In 1936, as a result of pressure from state structures, these two organizations were merged. The manager's duties were entrusted to M. Krivoshapkin, who, working in the city administration and in the work of other societies, was only fulfilling this duty formally. In 1939, the engineer left the society. 


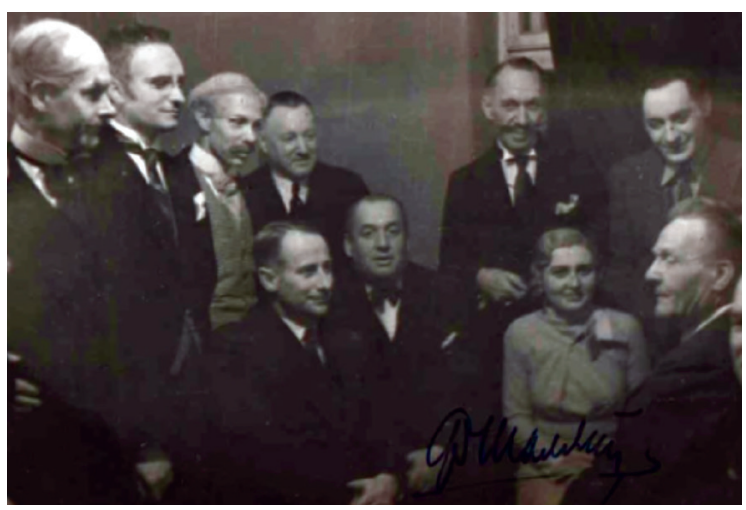

Figure 11.

Fyodor Shalapin with the Rigans at the Friendly Society of Russian Theatre. 1st row from left: 1st M. Krivoshapkin, 4th - F. Shalapin (1934) [37].

M. Krivoshapkin also visited the concerts, including at the end of 1934 was listening to the well-known Russian opera singer Fyodor Shalapin (Фёдор Шаляпин; 1873-1938) in Riga city and met with him in the Friendly Society of Russian Theatre.

From January to May 1941, M. Krivoshapkin worked as a Senior Engineer in the Planning Committee of the Executive Committee of Riga City. From May until his arrest on 14 June 1941, he was Chief Engineer and Head of Capital Construction of the Brick Trust [38].

Holidays and summers family (spouses and three children) spent in Jaunogre, where they built a wooden two-storey summer cottage by the project of Vladimir Shervinsky project.

According to the memories of M. Krivoshapkin's daughter Natālija, her father paid great attention to his children. M. Krivoshapkin was not indifferent to drawing and painting, which he taught his children, he taught them to be honest and hardworking people.

\section{End on Life of M. Krivoshapkin and His Descendants}

14 June 1941 was a fateful day for M. Krivoshapkin and his family. On this day in Krivoshapkins' apartment, like in many other Latvian apartments and homes, uninvited guests came into the form НКВД (NKVD) ${ }^{2}$. Vladimir Shervinsky is became an inadvertent witness to this event and his memories describe the situation well: «in the evening of 13 June everyone noticed that there were many large trucks at the crossroads of the city. .. And only on 14 June everything in the morning was explained, there were no more rumours. It was clear that lot of people are being arrested. Riga was silent, everyone was gloomy like shadows and in the evening a telephone call was made in our apartment. Misha (Mikhail Krivoshapkin) urged to immediately bring his suitcase, which for some reason was with us, as well as ropes to tie the belongings. It was clear

${ }^{2}$ НКВД - Народный комиссариат внутренних дел; People's Commissariat for Internal Affairs, Security Service of the Soviet Union 
that they broke in their apartment too. We took the suitcase, put some ropes in it and we went up to Škūnu iela in a hurry.

There was a chaos in the apartment, filled bags, various things were strewn around, three men were in the dining room, sitting at the table, writing something and a militiaman was standing by the door. It turned out that «guests» had arrived at his apartment at night, but in Riga there was only Borja (the eldest son of M. Krivoshapkin) and «guests» went in all of the rooms and said they were looking for someonesand then went away. Seeing that there is no uncle Misha, they left to Ogre city, but when they arrived there uncle Misha had already gone to Riga. «It is nothing,» they said, «let's take the family and he will get to know and come» and when uncle Misha arrived in the apartment in city, they were waiting there. Nina (spouse of Mikhail Krivoshapkin) fired from room to room, from the closet to the closet, not knowing what to take, what to do and occasionally caught up with unnecessary items because they only had two hours and the baggage was very limited. I ran after the ropes at Pankratov family, who lived in Mazā Kaleju iela. By the set time everything was ready. We were tightly embraced, but we didn't know we were seeing Misha, Nina and Volodechka for the last time» [39].

M. Krivoshapkin was deported to Ussolag in the Molotov region (at present - Perm region), but the family was sent to the Tomsk region. The main reason for his arrest and deportation was his participation in the Russian Gymnastics Society «Сокол» («Sokol»), especially the managerial position in it from 1934 to 1939. The prosecution of 23 March 1942 suggested that the case be referred to the Special Meeting of the USSR 3 НКВД (NKVD) and sentenced to the highest penalty - «execution by shooting» [40].

M. Krivoshapkin' dealt with the case was overviewed at special meeting only on 4 November 1942. The verdict was as follows: «For taking part in the counter-revolutionary fascist organization Mikhail Krivoshapkin is imprisoned for 10 years from the 14 June 1941» [41].

The health of engineer and public worker, M. Krivoshapkina, was already irreversibly damaged. On 6 April 1943 he went to eternity [42].

Remained in Siberia, Boris and Natālija continued the work of their fathers engineer after returning to Latvia. M. Krivoshapkins' grandchildren are graduates of RPI: Liena Ivonna Šervinska (daughter of Boriss) is a certified architect, while Vita Gudkova (daughter of Natālija) has finished RPI a civil engineer. The great-grandchildren of engineer M. Krivoshapkin study at Riga Building College - Dāvis Sprīzìtis as the civil engineer and Dita Sprīzite as the architect.
Life and

Professional Activities of a Graduate of the Department of Engineering of Riga Polytechnic Institute Mikhail Krivoshapkin (1888-1943) 


\section{LIST OF SOURCES AND LITERATURE}

[1] Jaunjelgavas Kristus Apskaidrošanas pareizticīgo baznīcas laulību registrs, 1898. gads. Latvijas Nacionāla arhīva Latvijas Valsts vēstures arhīvs (turpmāk - LNA LVVA) 232. f., 2. apr., 133. l., 14. lp.

[2] Aleksandr, Mitropolit Rizhskij i vseja Latvii. Preosvjashhennejshij Aleksandr (Zakkis) - pervyj pravoslavnyj episkop-latish. Latvijskij pravoslavnyj hronograf. Vypusk 2. Riga 2016, str. 5-18.

[3] Krivošapkinu ǵimene (1898). 1. rindā no kreisās: Aleksandra (18861955), Jevgenja (1855-1942), Mihails (1888-1943), Dmitrijs (1844-1906), Nataḷja (1892-1946); 2. rindā - Lidija (1878-1966), viṇu radinieki, trīs brāḷi Podprugini no Vologdas, Marija (1880-1968). Foto no Krivošapkinu dzimtas arhīva.

[4] M. Krivošapkina autobiogrāfija. Krivošapkinu dzimtas arhīvs.

[5] Tatjanas Upmanes (dzim. Šervinska) atmiņas. Šervinsku dzimtas arhīvs.

[6] RPI studentu registrs. LNA LVVA 7175. f., 1. apr., 1908. 1., 207. lp.

[7] Russkij ezhegodnik na 1938 god, na 1939 god. Riga: 1937-1938, str. 70, 73.

[8] M. Krivošapkins (1908). Foto no Krivošapkinu dzimtas arhīva.

[9] Krievu studentu korporācija «Fraternitas Arctica», 1908./1909. mācību gadā. No kreisās: Stepans Zaverñajevs (Степан Заверняев), Pjotrs Vinogradovs (Петр Виноградов), Mihails Krivošapkins, oldermanis Nikolajs fon Essens (Николай фон Эссен), Ivans Lasmans (Иван Лассман), Fridrihs Lēsmans (Фридрих Леесман). Foto no Krivošapkinu dzimtas arhīva.

[10] M. Krivošapkina autobiogrāfija. Krivošapkinu dzimtas arhīvs.

[11] M. Krivošapkips strādā ar nivelieri Jaunpiebalgā (1911). Foto no Krivošapkinu dzimtas arhīva. Foto no Krivošapkinu dzimtas arhīva.

[12] Izraksts no M. Krivosapkina diploma. 1914. gads. Krivošapkinu dzimtas arhīvs.

[13] Nina un Mihails Krivošapkini (1914). Foto no Krivošapkinu dzimtas arhīva.

[14] M. Krivošapkina autobiogrāfija. Krivošapkinu dzimtas arhīvs.

[15] Elevatora celtniecība Altatā (1916). Foto no Krivošapkinu dzimtas arhīva.

[16] M. Krivošapkina autobiogrāfija. Krivošapkinu dzimtas arhīvs.

[17] Ventspils. Pontona tilts [tiešsaiste]. https://www.europeana.eu/portal/de/ record/92085/Inb_zl_07158.html [skatīts: 10.03.2019].

[18] M. Krivošapkina autobiogrāfija. Krivošapkinu dzimtas arhīvs.

[19] Dzelzbetona tilta projekts pār Sarkandaugavas atteku (20. gadsimta 20. gadi). Foto no Krivošapkinu dzimtas arhīva.

[20] Vospominanija arhitektora V. M. Shervinskovo. Pravoslavije v Latvii. Sbornik statej pod redakcijej A. V. Gavrilina.. Riga: Filokalija, 2008, № 7, str. 112.

[21] Pravoslavije v Latvii. Riga: Institut filosofii i sociologii LU, 2014, Nr. 2 (11), str. 117.

[22] Iekarama tilta projekts pār Daugavu Rīgā. Krivošapkinu dzimtas arhīvs.

[23] Jumars. Beigtā «Libekas» tilta piemiṇai. Pūcesspieǵelis, 1924. gada 12. aprīlis, Nr. 15, 5. lpp. 
[24] Pontonu tilta būvniecība Rīgā (1931). Foto no Krivošapkinu dzimtas arhīva.

[25] Pontonu tilts Rīgā (20. gadsimta 30. gadi). Foto no Krivošapkinu dzimtas arhīva.

[26] M. Krivošapkina skolotāja cenza lieta. LNA LVVA, 1632. f., 1. apr., 10966. 1., 7.-13. lp.

[27] Es viṇu pazīstu: latviešu biogrāfiskā vārdnīca. Rīga: Biogrāfiska arhīva apgāds, 1939, 270. lpp.

[28] Skujenieks M. Latvijas Republikas Saeimas vēlēšanas 1925. gadā. Rīga: Valsts Statistiskā pārvalde, 1926, 156. lpp.

[29] Skujenieks M. Latvijas Republikas Saeimas vēlēšanas 1928. gadā. Rīga: Valsts Statistiskā pārvalde, 1929, 154. lpp.

[30] Skujenieks M. Latvijas Republikas Saeimas vēlēšanas 1931. gadā. Rīga: Valsts Statistiskā pārvalde, 1932, 15. lpp.

[31] Bulmerinks E. Rīgas Rīgas pilsētas domnieku vēlēšanas 28./29. martā 1931. g. Rìga, 1931, 30.-31. lpp.

[32] M. Krivošapkins (20. gadsimta 30. gadi). Foto no Krivošapkinu dzimtas arhīva.

[33] Latvijas krievu apvienības dokumenti. LNA LVVA 5645. f., 1. apr., 1.-8. l.

[34] Russkij ezhegodnik na 1938 god. Riga, 1937, str. 47-80.

[35] Coja S. Russkij institut universitetskih znanij v mezhvojennoj Latvii. Russkij mir v Latvii.Arabazhinskije kursi. Almanah. Vip. XXXII. Riga: izdanije onschestva Seminarium Hortus Humanitatis, 2013, str. 90-91, 151.

[36] Krievu vingrošanas biedrības «Sokol» biedru saraksti. LNA LVVA, 3285. f., 1.apr. 32., 34. l.

[37] Fjodors Šal̦apins ar rīdziniekiem Krievu teātra draugu biedībā. 1. Rindā no kreisās: 1. M. Krivošapkins, 4. F. Šal̦apins (1934). Foto no Krivošapkinu dzimtas arhīva.

[38] M. Krivošapkina autobiogrāfija. Krivošapkinu dzimtas arhīvs.

[39] Vospominanija arhitektora V. M. Shervinskovo. Pravoslavije v Baltii. Riga: Institut filosofii i sociologii. Riga, 2014, № 2 (11). str. 121.

[40] M. Krivošapkina lieta. LNA LVA, 1986. f., 2. apr., 8538. 1., 31.-32. lp.

[41] M. Krivošapkina lieta. LNA LVA, 1986. f., 2. apr., 8538. l., 22. lp.

[42] Dokumenti par M. Krivošapkinu. LNA LVA, 1986. f., 2. apr., 8538. l., 2. lp

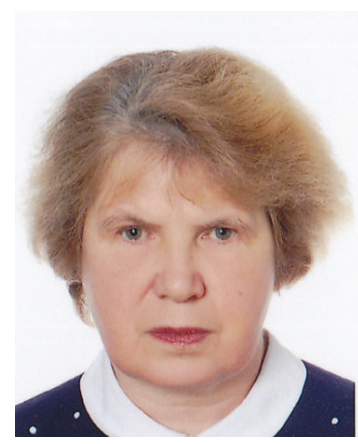

TATJANA FEIGMANE, $D r$. hist., has been a teacher at schools and a lecturer at universities. She was the manager of the project «Latvian Russians». Her main academic interests include the history of Russians in Latvia, their schools, organisations, etc. Phone: 37129517470

E-mail: t.feigmane@inbox.lv 


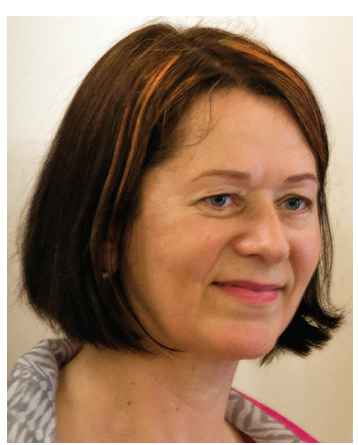

LIENA IVONNA ŠERVINSKA, Mg. arch., alumnus of RPI (1983) and is an architect and painter. She worked as a lecturer at Riga Building College (19871991), since 1991 holds private practice in architecture; designs mansions, public and industrial buildings, carries out reconstructions and renovations for apartments and designs interiors. Operates in Folk Art Studio «Kolorits» (since 2009 - Folk Art Studio «Grīva»). Since 2010 had prepared seven oneman exhibitions.

Phone: +37129148650

Tatjana Feigmane, Liena Ivonna Šervinska

\section{Rīgas Politehniskā institūta Inženieru nodaḷas absolventa Mihaila Krivošapkina (1888-1943) dzīves gājums un profesionālā darbība}

Rīdzinieks, Rīgas Politehniskā institūta (RPI) Inženieru nodal̦as absolvents (1914) Mihails Krivošapkins pēc studijām strādāja par inženieri Krievijā, kur būvēja elevatorus. No 1920. gada līdz izsūtīšanai uz Sibīriju 1941. gadā dzīvoja Rīgā un bija vairāku Latvijas tiltu projektu autors, strādāja par inženieri Rīgas būvvaldē, bija Rīgas domes deputāts (1925-1934). Darbojās dažādās sabiedriskās organizācijās. Inženiera darbu turpina viṇa pēcnācēji - mazbērni un mazmazbērni.

Atslēgas vārdi: Mihails Krivošapkins, Rīgas Politehniskā institūta absolventi, Latvijas inženieri.

Татьяна Фейгмане, Лиена Ивонна Шервинска

Жизненный путь и профессиональная деятельность Михаила Кривошапкина (1888-1943), выпускника Инженерного отделения Рижского политехнического института

Рижанин, выпускник (1914) Инженерного отделения Рижского политехнического института (РПИ) Михаил Кривошапкин после учебы работал инженером в России, где строил элеваторы. С 1920 года до депортации в Сибирь в 1941 году он жил в Риге и был автором нескольких проектов мостов в Латвии, работал инженером в Рижской Стройуправе, был депутатом Рижской думы (1925-1934). Работал в различных общественных организациях. Деятельность инженера продолжают его потомки - внуки и правнуки.

Ключевые слова: Михаил Кривошапкин, выпускники Рижского политехнического института, инженеры Латвии. 